\title{
GRAMMATICAL ISSUES IN JUDICIAL INTERPRETATION - DOES LEGAL PRACTICE NEEDS LINGUISTIC THEORY? BASED ON POLISH COURTS' DECISIONS
}

\author{
MATEUSZ ZEIFERT \\ Silesian University in Katowice \\ ul. Armii Ludowej 13/10,44-121 Gliwice \\ mateusz.zeifert@gmail.com
}

Most interpretational problems in law pertain to the meaning of words. However, in this paper I address problems caused in Polish courts by grammar (namely: syntax and inflexion) of legal provisions. One can distinguish five main sources of grammatical issues in judicial interpretation of law: syntax of a sentence (i.e. order of words), conjunctive words (i.e. $i, l u b$ ), punctuation marks (i.e. comma, semicolon, dash), nominal grammatical categories (i.e. number, gender), verbal grammatical categories (i. e. aspect, tense, mood). Traditional Polish canons of interpretation offer no clues on how to deal with such issues, stating only that statutes should be construed in accordance with the rules of grammar. In fact, cases in which such interpretational issues occur, are decided in a highly incoherent manner. The courts tend to feel a tension between grammatical form of a provision and its purpose, function, or other extra-linguistic values. I think the main reason of such controversy is a very 
limited vision of grammar shared by the courts, stemmed from primary school rather than contemporary linguistic theories.

Keywords : legal interpretation, judiciary, grammar, syntax, ambiguity

\section{GRAMATYCZNE PROBLEMY INTERPRETACJI PRAWA - CZY PRAKTYKA PRAWNICZA POTRZEBUJE TEORII LINGWISTYCZNEJ? ANALIZA ORZECZNICTWA POLSKICH SĄDÓW}

Większość problemów w interpretacji prawa tyczy się znaczenia słów zawartych w przepisach. W niniejszym tekście chciałbym poruszyć jednak problemy, które są powodowane przez gramatykę przepisów. Można wyróżnić pięć głównych źródeł tego rodzaju problemów: budowa składniowa zdania (np. szyk wyrazów), spójniki (np. $i, l u b$ ), interpunkcja (np. przecinek, średnik, myślnik), deklinacyjne kategorie gramatyczne wyrazów (np. liczba, rodzaj), koniugacyjne kategorie gramatyczne wyrazów (np. aspekt, czas, tryb). Tradycyjne polskie dyrektywy wykładni nie oferują niemal żadnych wskazówek co do radzenia sobie z tego typu problemami. Co najwyżej można spotkać się z banalnym zaleceniem, by przepisy prawa interpretować zgodnie z regułami gramatyki języka polskiego. W praktyce tego typu sprawy są rozstrzygane w sposób wysoce niekonsekwentny. Sądy często dostrzegają sprzeczność pomiędzy formą gramatyczną przepisu, a jego celem, funkcją czy innymi pozajęzykowymi wartościami. W moim przekonaniu wynika to $\mathrm{W}$ dużej mierze $\mathrm{z}$ faktu, iż wizja gramatyki, jaką dysponują jest bardzo ograniczona - wywodzi się raczej z programu szkoły podstawowej niż ze współczesnych teorii lingwistycznych.

Słowa klucze: interpretacja prawa, orzecznictwo, gramatyka, składnia, wieloznaczność

\section{Introduction: aim of the study, methodology and definitions}

In the act of interpreting statutes, one can encounter various linguistic problems. Most of them pertain to the meaning of words. For instance, there are ambiguity and vagueness, amongst other phenomena, that draw the attention of both legal theory and legal practice (see: Endicott 2001, Solan 2010: 48, Tobor 2013). As Lawrence Solan puts it: 
'Because so many of the interpretive problems in the law are lexical, legal scholars have tended to think of meaning, and even language, as dealing almost exclusively with the meanings of words' (Solan 2001: 245). However, there is also the grammatical aspect of language. And accordingly, there are grammatical issues of statutory interpretation. In this paper, my aim is to identify these issues, categorize them, show how they are dealt with and ask a question about the usefulness of linguistic theory for legal practice.

The following analysis is based on a quasi-empirical research of the decisions in which Polish courts deal with grammatical problems of interpretation. Let me briefly present employed methodology. First, using one of the available legal databases (Lex Omega by Wolters Kluwer), I selected judicial decisions featuring keywords related to grammar (like grammar, grammatical, syntax, syntactical, case, number, gender, aspect, mood, tense, etc.). I restricted my research to the decisions of the highest courts in Polish legal system, namely the Supreme Court (Sąd Najwyższy) and the Supreme Administrative Court (Naczelny Sąd Administracyjny), although it should be noted that I made several exceptions for the decisions of lesser courts that I found particularly interesting. Then I read all of the selected decisions and I eliminated those in which the keywords happened to have nothing to do with statutory interpretation. Finally I eliminated those which were repeated or otherwise uninteresting. This left me with a sample of over two hundreds judicial decisions. Of course said procedure cannot be fully considered 'empirical' and it does not allow me to make any quantitative claims. However I think that it gives a pretty good picture of grammatical problems that occur in Polish practice of statutory interpretation.

To begin my analysis, I need to introduce definitions for two pivotal terms that will be extensively used. The first term is 'grammar'. I accept a very traditional sense of grammar, namely that it is a set of rules governing creation of words, their modification according to different grammatical categories and combining them into compound expressions, like clauses, phrases and sentences. In other words I define grammar as the rules of word-formation, inflection and syntax. This is indeed kind of a school-like approach to grammar. I am aware of more modern approaches and they will be briefly discussed in my conclusions. However, this traditional sense of grammar is exactly the 
one shared by Polish courts, or actually Polish judges, and therefore it is appropriate for my purposes in this paper.

The second pivotal term is 'statutory interpretation' (henceforth referred to as simply 'interpretation'). The definition of interpretation is a controversial issue in legal theory. There are competing theories for both descriptive (what it is), as well as normative (how it should be done) nature. The definition that I accept stems from the work of Jerzy Wróblewski (see: Wróblewski 1990, Opałek i Wróblewski 1991) and was accepted by many influential contemporary scholars (MacCormick i Summers 1991: 12). It is particularly suitable for discussing problems of legal practice. According to this definition 'interpretation' is not just any process of ascribing meaning, but a process of ascribing meaning to a legal text in which some argumentation is involved in order to justify the way it is understood. Such concept of interpretation is sometimes referred to as interpretation sensu stricto as opposed to interpretation sensu largo, which might correspond better with linguists' intuitions (Wróblewski 1990: 55-9).

Summing up, according to two previously mentioned definitions, a grammatical issue of judicial interpretation would be a situation in which a grammatical feature of a provision causes uncertainty of how it should be understood and it is explicitly discussed by court deciding the case. Therefore it is restricted to the cases in which the question of grammar becomes a part of the argumentation.

\section{Classification of grammatical issues}

Having clarified two crucial notions we are now ready to start the analysis. My research has shown that from a linguistic point of view grammatical issues in judicial interpretation can be divided into two main categories. The first category is problems of syntax. It groups problems caused by ambiguity of syntactic relations between words in sentences. Most of the time, such problems are resolved automatically and unreflectively - linguistic or extralinguistic context solves them entirely and we do not even notice them (Solan 2010: 31-3). Yet every once in a while the context does not suffice and interpretative problems emerge. These can be further divided into problems with sentence 36 
structure, problems with conjunctive words and problems with punctuation marks. The second category is problems of meaning, or more specifically, problems of reference. They are caused by indeterminacy of relations between grammatical categories of words and extralinguistic reality. These can be viewed as a special case of the legal acts' open-texture (Hart 1961: 171-186). They can also be subdivided into problems with nominal and verbal grammatical categories. Below, I will elaborate on each of these categories and provide examples taken from Polish judicial decisions.

\section{Sentence structure}

Problems with the sentence structure are instances of typical syntactic ambiguity, the one that Noam Chomsky made so famous with his example: 'Flying planes can be dangerous' (Chomsky 1965: 41-2). Interestingly, in American literature an analogous case was noted (Farell 2008: 37-41). The insurance policy at issue excluded from coverage any loss caused directly or indirectly by '[f]lood, surface water, waves, tides, tidal waves, overflowing of any body of water, or their spray, all whether driven by wind or not.' The interpretative problem was whether the word 'overflowing' is a gerund or a participle. In other words, does the rule excludes only flood, tides etc. that overflow or the overflowing itself.

Polish language is morphologically different and therefore it is impossible to find exactly the same kind of problem in Polish case law. However, the most common syntactic problems with sentence structure also have to do with so called enumerative provisions -provisions which include an enumeration of objects, features, conditions etc. Such enumerations often include an expression modifying other expressions (called a modifier - usually an adjective or a relative clause). Sometimes it is not clear whether a modifier refers to all elements of the enumeration or only to the element directly next to it.

In one of the Polish tax statutes, there is a provision providing tax relief for 'expenses incurred for (...) the purchase of individual equipment, devices and technical tools necessary for rehabilitation and 
facilitating life activities'". The interpretative problem that was raised over and over again upon this provision goes like this: does the adjective 'individual' refer only to 'equipment' or to the whole phrase: 'equipment, devices and technical tools'? It is an important practical question. Imagine yourself being a disabled person and buying a cell phone. Is this purchase tax-free? No doubts that it would facilitate your life activities. On the other hand it is no equipment, rather a device (at least as long as the semantics of Polish language is concerned). And it is surely not individual - it has no individual features. So, must devices and technical tools also be individual in order to be tax-free? Not surprisingly, administration institutions tend to decide that they must (for then they are not tax-free), but administrative courts regularly overrule they decisions recognizing that only equipment needs to be individual, whereas devices and technical tools do not. What is quite confusing is that both institutions and courts argue that their decisions are determined purely by the rules of grammar.

\section{Conjuctions}

Next subcategory of syntactic issues consists of problems caused by conjunctive words - words that join other words and phrases. In English legal language there are generally two problematic words of this type: and and $o r^{2}$. In some states of America their meaning was fixed by the legislature itself in an interpretation act (Scott 2010: 360), but generally courts (and scholars) are left to deal with them on their own. Their analyses are very interesting as they include numerous linguistic and extralinguistic factors, like in example: sentence structure, grammatical

\footnotetext{
${ }^{1}$,wydatki poniesione na (...) zakup i naprawę indywidualnego sprzętu, urządzeń i narzędzi technicznych niezbędnych w rehabilitacji oraz ułatwiających wykonywanie czynności ży ciowych", art. 26 ust. 7a pkt 3 ustawy z dnia 26 lipca 1991 r. o podatku dochodowym od osób fizy cznych (Dz.U.2016.2032 j.t.).

${ }^{2}$ There is also the infamous hybrid word and/or that was characterized in a 1935 court decision as 'that befuddling nameless thing, that Janus-faced verbal monstrosity, neither word nor phrase, the child of a brain of someone too lazy or too dull to know what he did mean' (Employers Mutual Liability Insurance Co. v. Tollefson, 263 N.W. 376 at 377 (1935).
} 
number, type of provision, punctuation, articles, sentence context etc. (see: Kirk 1970-1971: 242-6, Adams i Kaye 2007: 1167-9).

Polish language includes more conjunctive words, though most of them can be roughly translated as and (i, oraz, a, a także, jak równiez, etc.) or $o r(l u b, a l b o, b a d z ́)$. As Polish legal culture is heavily influenced by formal logic, courts tend to interpret them with reference to logicians' conventions rather than linguistics. There is an established assumption that words $i$ and oraz represent the relation of conjuction, while words $l u b$ and albo represent the relation of alternative (see: Malinowski 2008: 66-7). Still, that leaves a lot of space for controversies. Logical relations are obviously very precise and rigid. At the same time these words have also ordinary meaning which is similar, but less precise, more diversified, subtle and context-dependent. In the end courts are often left with the choice between logical and ordinary meaning of conjuctions, not to mention that both in formal logic and in ordinary language these conjunctive words may also be ambiguous. Let us now discuss one of such examples.

The provision prohibits 'storage and carrying of arms and ammunition in such a way as to allow unauthorized persons to have access to them" 3 . The defendant was caught carrying two cartridges for a hunting rifle and no rifle. Did he commit this crime? The answer depends on how we interpret the word 'and' (pol. $i$ ). If it formulates a logical relation of conjunction - the answer would be 'no', because he met only one of its two necessary conditions. If we interpret it more liberally, we can say that the rule is violated regardless of which of its two conditions is met.

In his defense the defendant insisted that word and used in the provision represents logical relation of conjuction, and therefore to be found guilty of this crime, an offender must carried both a firearm and ammunition. As a proof he pointed to other provisions of the statute where words 'arms' and 'ammunition' are joined by the word 'or' (pol. $l u b$ ) instead of 'and'. Supreme Court rejected the defendant's argumentation and ruled that the statute is offended even if the offender carried only ammunition (or only a firearm). The court noted that the

\footnotetext{
${ }^{3}$ „Tej samej karze podlega, kto: (...) przechowuje oraz nosi broń i amunicję w sposób umożliwiający dostęp do nich osób nieuprawniony ch...", art. 51 ust. 2 pkt 7 ustawy z dnia 21 maja 1999 r. o broni i amunicji (Dz.U.2012.576 j.t.).
} 
word and (pol. $i$ ) is often used not to introduce conjunction, but simply to enumerate things. That is certainly true. However, the court did little to prove that this was the case. It mostly relied on a purposive argumentation and called the defendant's interpretation absurd, and yet it did not really bothered about the purpose of the statute and failed to show what is exactly absurd about not construing an ambiguous criminal statute against the defendant.

There are many similar examples in which Polish courts struggle with conjunctive words. Other than $i$ and oraz (eng. and), the most problematic words would be lub and albo (eng. or), usually considered to be representing logical relation of alternative. Logicians, however, distinguish two kinds of alternative: inclusive and exclusive, which is something hard to represent in ordinary language. In the end, words like $l u b$ are construed in many different ways: sometimes as a conjunction, sometimes as an inclusive alternative and sometimes as an exclusive alternative.

\section{Punctuation marks}

The last subcategory of syntactic issues refers to the use of punctuation marks in legal provisions. Strictly speaking, punctuation is not a part of grammar - it is barely a graphic notation of intonation, accent and other prosodic factors (Jodłowski 2002: 22-3). However in many languages, including Polish, the function of punctuation is mostly syntactic, and that is what justifies its inclusion in my analysis. Apparently, other legal scholars also tend to treat punctuation as a part of grammatical aspect of language (Scalia i Garner 2012: 160, Jellum 2008: 81).

In the Anglo-American legal world, punctuation in statutory language is generally treated with distrust. There is a historical rationale behind it. In England, marginal notes like punctuation were for centuries not considered to be part of a statute because they were inserted by a clerk only after the statute hadbeen enacted by Parliament. Punctuation was something that was not voted on and courts acknowledged that. Things changed in the middle of the nineteenth century, but the theory of statutory interpretation did not. American courts at first followed strictly the English tradition, in spite of different 40 
legislative environment. In some States this tradition has even become codified in interpretation acts (Scott 2010: 360-1). However, since the beginning of the twentieth century, this suspicious attitude towards punctuation started to change. Nowadays many influential scholars from both intentionalist and textualist camps approve resorting to statute's punctuation as an acceptable indicator of meaning (Marcin 1977: 245, Jellum 2008: 81, Scalia i Garner 2012: 162).

In Polish legal culture this subject has never drawn much attention, despite challenging legal practice from time to time. There are at least ten punctuation marks used in Polish language, but it seems that interpretative problems are caused only by some: semicolon (;), hyphen (-), brackets (()) and - most of all - comma (,). Actually comma is infamous for being highly problematic in everyday language too. This is mostly due to its multifunctional character. It can be used to construct enumerations, to substitute different conjunctive words, to divide independent phrases in sentences, to separate main and additional information, as well as for purely orthographical, or rhythmic, reasons. And on top of all that, there is always the risk that a comma was placed erroneously due to a scrivener's error. Let me present one of such examples.

Probably the most famous example of a problematic comma in Polish legislation was from the Penal code, enacted in 1997. There was an obvious scrivener's error in one of the provisions. The promulgated version stated that 'whoever causes (...) severe illness that is incurable or prolonged illness that is life-threatening (...) shall be punished...'4. What it missed was a lone comma after the word 'prolonged'. In result, according to the promulgated version there were two categories of illnesses: severe illness that is incurable and prolonged illness that is life-threatening, whereas there should be three: severe illness that is incurable, severe illness that is prolonged, and: illness that is lifethreatening. That slight change in punctuation had serious consequences, because it restricted the scope of the rule. As you may imagine it is much harder to cause a prolonged illness that is life-

4 ,Kto powoduje ciężki uszczerbek na zdrowiu w postaci (...) ciężkiej choroby nieuleczalnej lub długotrwałej choroby realnie zagrażającej życiu", art. 156 § 1 pkt 2 ustawy z dnia 6 czerwca 1997 r. Kodeks karny (Dz.U.2016.1137 j.t.). 
threatening than it is to cause an illness that is life-threatening, but not necessarily prolonged. The legislative history was somewhat ambiguous on this issue, because the error went unnoticed up until the final stages of legislative procedure. However the factual drafters' intention was clear enough. And yet courts - faithful to their expected role in a statutory law country such as Poland - refused to amend this error on their own. They found the way out, though. Namely they started to interpret the word 'prolonged' in a very peculiar manner, for example stating that a 'prolonged' illness does not really need to last long. In the end, the lawmaker's intention was respected, only it was the word-meaning, not the punctuation, that suffered.

\section{Nominal grammatical categories}

Let us now move to the problems of different nature. It is often unclear whether a given statutory word - due to its grammatical category - does refer to a certain factual situation or not. Such controversy has nothing to do with syntax of a provision. It can rather be viewed as a problem of 'classification' (Tobor 2013: 215) or 'fact-oriented interpretation' (Guastini 2006: 143). Therefore I label this kind of problems semantic or - more precisely - referential. One subcategory of such problems is caused by nominal grammatical categories, mostly number ${ }^{5}$.

In Polish language - just as in English - there are generally two forms of words: singular and plural. A common question is: does a noun in singular form refers also to plural objects in extralinguistic reality? And vice versa - does a plural noun refers also to a single object? In many Common Law systems such issues are regulated by an interpretation act (see: Irish Interpretation Act 2005, Canadian Interpretation Act 1985, British Interpretation Act 1978, Scott 2010: 369-71). This problem is not a new one. Jeremy Betham, a famous English lawyer and philosopher of the nineteenth century, discussed the crime of 'stealing horses'. He insisted that somebody who stole only one horse did not commit this crime, because of the rule of lenity -

\footnotetext{
${ }^{5}$ Due to inflexional nature of Polish language, other nominal categories like gender or case may rather cause a syntactic ambiguity which has been already discussed.

42
} 
stating that ambiguities in criminal law should be resolved in favor of a defendant (Scalia i Garner 2012: 131). On the other hand, a contemporary French legal scholar claims that the crime of 'kidnapping juveniles' is commited even if only one juvenile was kidnapped. The opposite interpretation he calls absurd (Rabault 1997: 58).

The same problem occurs also in Polish law. There is an illustrative example of a criminal rule: "Whoever breeds or keeps greyhounds (...) without permission shall be punished..." ${ }^{6}$. Note that the word 'greyhounds' is used in plural form. The defendant had a single greyhound without permission and the obvious question was: did he commit the crime? On the one hand - there is the literal meaning of the statute, coupled with the rule of lenity, or rather its latin equivalents known in Poland: Nullum crimen sine lege and In dubio pro reo. On the another hand, there is the common sense and the purpose of the statute, namely the protection of wild animals. Polish Supreme Court decided that a plural form of a noun in a provision does not limit its scope to plural objects only. As a proof the court discussed dozen or so examples from other criminal statutes in which plural nouns obviously refer to single objects and their form is dictated purely by stylistic reasons. It also adhered to the statute's purpose which would undoubtedly be breached should the defendant's interpretation prevailed. The argumentation was smart and convincing, nevertheless the decision raised a lot of controversy among criminal law scholars.

\section{Verbal Grammatical categories}

Another subcategory of referential issues groups problems caused by verbal grammatical categories, like tense, aspect, mood, voice, etc. In American literature verbs are said to be "probably the most important words in the English language and are most likely to affect the outcome of a legal case'; the most common verbal categories to have legal consequences being mood and voice (Farell 2008: 2). Polish language

\footnotetext{
${ }^{6}$ „Kto hoduje lub utrzymuje bez zezwolenia charty rasowe lub ich mieszańce podlega karze...", art. 52 pkt 4 ustawy z dnia 13 października 1995 r. Prawo łowieckie (Dz.U.2015.2168 j.t.).
} 
differs much from English in the grammar of verbs, and therefore those issues are a little difficult to discuss. Mood and voice hardly ever cause any interpretative problems and the most problematic are tense (past, present, future) and aspect ${ }^{7}$. The following example includes the question of tense.

The provision stipulates that a prisoner who 'will not return' to prison on a certain date, shall be punished ${ }^{8}$. The question was: when exactly is this crime committed? On that particular day when he should have returned and he did not? Or maybe during the whole period between that day and the moment he was finally caught, which would make the crime a continued one (a notion well-known in Polish criminal law doctrine)? It was a very important question, because there was a new statute coming into force on a certain day and the offender had a chance of not being punished at all. The answer, however, was not easy. The appellate court claimed that 'will not return' has a different meaning than 'does not return' and therefore the crime is committed only on a particular day. This decision was overruled by the Supreme Court, who stated: 'will not return' has a different meaning than 'did not return' and therefore the crime is committed during a period of time. The conclusion of Supreme Court's opinion sounds somewhat funny, because it involved all possible tenses: "Will not return" should be understood as "did not return and is still not returning". Once again we can see that different courts draw different conclusion from the same grammatical feature of a provision and claim that their decision is dictated purely by the grammar of the statutory language.

\footnotetext{
${ }^{7}$ There are two aspects in Polish: perfective and imperfective. Yet it should be noted that they differ from their English equivalents both in terms of meaning and form (i.e. they are usually introduced on a morphological level).

8 „nie powróci...”, art. 242 § 3 ustawy z dnia 6 czerwca 1997 r. Kodeks karny (Dz.U.2016.1137 j.t.). 


\section{What about linguistic theory?}

Those five cases discussed above are barely a few examples. I have chosen them based on their illustrative value and ease of translation. They certainly do not cover the whole range of the subject matter. The research as a whole, though, allows me to draw some conclusions.

First, I must admit that Polish judges generally make a good use of grammatical terminology. In my research I have encountered only a few instances of mistakes regarding the use of grammatical terms, two of the most common being: confusing the verbal category of tense with the category of aspect and mistaking a gerund for a verb. Such mistakes rarely affect the power of courts' argumentation, not to mention the outcome of cases. Admittedly, Polish judges know the necessary grammatical terminology.

And yet cases featuring grammatical arguments happen to be decided in a highly incoherent manner. It is not uncommon for a lower court (or an administration institution) and a higher court to disagree upon a given case, while claiming that both their interpretations are dictated by the rules of grammar. In fact one may go as far as quote Karl Llewelyn that 'there are two opposing canons on almost every point' (Llewelyn 1950: 401). Below I present a list of opposing directives of interpretation used by Polish courts in 'grammar cases', inspired by his famous 'thrust-but-parry' canons of construction list (Llewelyn 1950: 401-6).

1A. A modifier at the end (beginning) of an enumeration refers only to the last (first) element of such enumeration.

2A. The word and requires that all conditions joined by it be realized altogether (conjunctive meaning).
1B. A modifier at the end (beginning) of an enumeration refers to all elements of such enumeration.

2B. Word and does not require that all conditions joined by it be realized altogether (enumerative meaning). 
3A. The word lub (English: or) has a different meaning than the word albo (English: or).

4A. In absence of a proper conjunctive words, a comma dividing elements of an enumeration has enumerative meaning.

5A. Singular and plural noun forms have different meanings.

6A. A singular noun form indicates a general quantifier (i.e. every).

7A. An imperfective aspect of a verb form means that the denoted action has an iterative character.

8A. A future tense of a verb form means that the denoted action should occur in the future.
3B. Words lub (English: or) and albo (English: or) have identical meaning.

4B. In absence of a proper conjunctive words, a comma dividing elements of an enumeration has conjunctive meaning.

5B. Singular and plural noun forms have identical meaning.

6B. A singular noun form indicates a existential quantifier (i.e. any).

7B. An imperfective aspect of a verb form does not mean that the denoted action has an iterative character.

8B. A future tense of a verb form does not mean that the denoted action should occur in the future.

How is that possible? My impression is that judges are sometimes deceived by the rules of grammar. They resort to them in search for precision and certainty, when they are not to be found there. Solan is absolutely right claiming that ' $[\mathrm{m}]$ ost battles over legal interpretation are battles about the meanings of words. Grammatical rules typically remain in the background unnoticed' (Solan 2001: 244). Yet every once in a while, when they are noticed, it is usually because of their limitations. First, there is syntactic ambiguity, resulting from sentence structure, conjunctive words, or punctuation. In case of syntactic ambiguity the rules of grammar offer no solution, because by definition - their allow more than one legitimate interpretation. In other words - they say too much. Second, there is referential 
indeterminacy, resulting from nominal or verbal grammatical categories. In case of referential indeterminacy the rules of grammar offer no solution, because grammatical categories do not represent extralinguistic reality in one-to-one relation. Their relation to reality is more or less indirect, even metaphorical (Langacker 2008: 698-702, Taylor 2002: 472). It other words - they say too little.

Judges do not often recognize this aspect of grammar. This is probably due to the understanding of grammar they share - this traditional, school-like notion that I have defined at the beginning of this paper. They tend to think of grammar as a complete set of very precise, rigid rules, on pair with the rules of formal logic. That is why the feel restricted by them so much and keep arguing that their decisions are dictated by the rules of grammar even in the cases of syntactic ambiguity or referential indeterminacy.

In the end it is not grammatical terminology, but rather a particular notion of grammar that judges lack. I would advocate for a less formal, more functional approach to grammar that would extend the scope of interpretative possibilities rather than narrowing it, and that would embrace the role of other meaningful factors, like word-meaning, linguistic and extralinguistic context, purpose of the statute, etc. Traditional approach, instead, tends to conflict with them and creates an unhealthy tension between 'form' and 'spirit' of statutory language. It is this tension that is responsible for the incoherence of decisions in 'grammar cases'.

The approach I amadvocating for can be found, amongst others theories, in the field of cognitive linguistics. Cognitive linguistics is currently regarded the dominant linguistic theory in the academic world. Actually, it is not a single theory, but rather a group o theories, including cognitive grammar (Ronald Langacker), conceptual metaphor (George Lakoff, Mark Johnson), prototype semantics (Eleanor Rosch, John Taylor), mental spaces and conceptual blending (Gilles Fauconnier, Mark Turner) and many others. Their common denominator is the idea that language is not an abstract phenomena of social nature (Saussure's claim), nor an autonomous faculty of human mind (Chomsky's claim), but a part of human cognitive system, and thus based on more rudimentary capacities of human brain such as perception, categorization and memory. Meaning is therefore grounded in our sensual experience. And it is this embodied meaning, not form, 
that is primary in language and that motivates various linguistic phenomena, including grammar.

It is quite unfortunate that legal scholars, so obsessed with language and twentieth century's philosophy of language, have been almost completely ignoring the development of modern linguistics. While the ground-breaking works of Ferdinand de Saussure or Noam Chomsky arguably did not offer much in terms of legal theory, the work of Langacker, Lakoff and others, obviously do. Some of them in fact have addressed this issue directly (see: Lakoff 1989, Johnson 2002, 2007, Turner 2013). They also inspired several legal scholars, who successfully applied concepts like conceptual metaphor, prototype semantics or radial categories to the problems of legal theory and even legal dogmatics (see: Winter 2001, Solan 2001 (red.), Berger 2004, Schane 2006, Dyer 2007, Osenga 2011, Manzanares 2014). Still, I believe cognitive linguistics have much more to offer to legal theory and the theory of statutory interpretation in particular. A fresh, more functional and flexible approach to the grammar of legal texts is just one example.

\section{Bibliography}

Adams, Kenneth A. and Alan S. Kaye. 2007. Revisiting The Ambiguity of "And" and "Or" in Legal Drafting. St. John's Law Review vol. 80: 1167-98.

Berger, Linda L. 2004. What is the Sound of a Corporation Speaking? How the Cognitive Theory of Metaphor Can Help Lawyers Shape the Law. Journal of the Association of Legal Writing Directors 2004/2, vol. 169: 169-208.

Chomsky, Noam. 1965. Aspects of the Theory of Syntax. Cambridge, Massachusetts: The Massachusetts Institute of Technology. (Polish edition: Zagadnienia teorii składni. 1982. Transl. I. Jakubczak. Wrocław-Warszawa-Kraków-Gdańsk-Lódź: Ossolineum).

Dyer, Charles R. 2007. The Queen of Chula Vista: Stories of SelfRepresented Litigans and a Call for Using Cognitive 
Lingusitics to Work with Them. Law Library Journal 99: 71756.

Endicott, Timothy. 2001. Vagueness in law. Oxford: Oxford University Press.

Farrell, Robert C. 2008. Why Grammar Matters: Conjugating Verbs in Modern Legal Opinions. Loyola University Chicago School of Law Law Review, vol. 40: 1-44.

Guastini, Riccardo. 2006. A Sceptical View on Legal Interpretation. In Analisi e diritto 2005. Ricerche di giurisprudenza analitica, ed. by Paolo Comanducci and Riccardo Gaustini, 139-144. Torino: Giappichelli.

Hart, Herbert L.A. 1961. The Concept of Law. Oxford: Oxford University Press (Polish edition: Pojęcie prawa. 1998. Transl. J. Woleński. Warszawa: Wydawnictwo PWN.

Jellum, Linda D. 2008. Mastering Statutory Interpretation. Durham: Carolina Academic Press.

Jodłowski S. 2002. Zasady Interpunkcji. Podręcznik. Wydanie nowe, zmienione $i$ rozszerzone, ed. Jan Gostyń. Kraków: Wydawnictwo Tomasz Strutyński.

Johnson, Mark. 2002. Brooklyn Law Review 67, no. 4: 949-62.

Johnson, Mark. 2007. Mind, Metaphor, Law. Mercer Law Review 58/3: 845-68.

Kirk, M. B. 1970-1971. Legal Drafting: The Ambiguity Of "And" and "Or", Texas Tech Law Review, vol 2: 235-53.

Lakoff, George. 1989. Cognitive Science and the Law. Toronto: University of Toronto.

Langacker, Ronald W. 2008. Cognitive Grammar: a Basic Introduction. New York: Oxford University Press (Polish edition: Gramatykakognitywna. Wprowadzenie. 2009. Transl. E. Tabakowska, M. Buchta, H. Kardela, W. Kubiński, P. Łozowski i in. Kraków: Universitas).

Llewellyn, Karl N. 1950. Remarks on the Theory of Appellate Decision and the Rules or Canons about How Statutes Are to Be Construed. Vanderbilt Law Review, vol. 3: 395-406.

MacCormick, Neil i Robert S. Summers. 1991. Interpreting Statutes. A Comparative Study, ed. Neil MacCormick, Robert S. Summers. Routledge: Dartmouth-Worcester. 
Malinowski, Andrzej. 2006. Polski język prawny. Wybrane zagadnienia. Warszawa: Wydawnictwo LexisNexis.

Malinowski, Andrzej. 2008. Redagowanie tekstu prawnego. Wybrane wskazania logiczno-jezzykowe. Warszawa: Wydawnictwo LexisNexis.

Manzanares Javier V. 2014. Cognitive Linguistics and the Law. Anuari de Filologia. Estudis de Linguistica 4: 185-200.

Marcin, Raymond B. 1977. Punctuation and the Interpretation of Statutes, Connecticut Law Review, vol. 9: 227-45.

Opałek, Kazimierz and Jerzy Wróblewski. 1991. Prawo: Metodologia, filozofia, teoria prawa. Warszawa: Pastwowe Wydawnictwo Naukowe.

Osenga, Kristen. 2011. A Penguin's Defence of the Doctrine of Equivalents: Applying Cognitive Linguistics to Patent Law. New York University Journal of Law \& Liberty 6:313-58.

Rabault, Hugues. 1997. Les limites de l'interpretation juridictionelle (Polish edition: Granice wykładni sędziowskiej, Warszawa 1997. Tłum. B. Janicka. Warszawa: Wydawnictwo Naukowe Scholar).

Scalia, Antonin and Bryan A. Garner. 2012. Reading Law: the interpretation of legal texts. St. Paul, MN: Thomson/West.

Schane Sanford A. 2006. Language and the Law. London-New York: Continuum.

Scott, J. 2010. Codified Canons and the Common Law of Interpretation, Georgetown Law Journal, vol. 98: 341-431.

Solan, Lawrence (ed.) 2001. Symposium: Cognitive Legal Studies: Categorization and Imagination in the Mind of Law. A Conference in Celebration of the Publication of Steven L. Winter's Book, A Clearing in the Forest: Law, Life, and Mind, Brooklyn Law Review vol. 67, no. 4.

Solan, Lawrence M. 2010. The Language of Statutes. Laws and Their Interpretation. Chicago-London: The University of Chicago Press.

Solan, Lawrence. 2001. Why Laws Work Pretty Well, but not Great: Words and Rules in Legal Interpretation. Review of Words and Rules: the Ingredients of Language by Steven Pinker. Law and Social Inquiry 26: 243-71. 
Taylor, John. 2002. Cognitive Grammar (Oxford Textbook in Linguistics). Oxford-New York: Oxford University Press (Polish edition: Gramatyka kognitywna. 2007. Transl. M. Buchta, Ł. Wiraszka. Kraków: Universitas).

Tobor, Zygmunt. 2013. W poszukiwaniu intencji prawodawcy. Warszawa: Wolters Kluwer Polska.

Turner, Mark and Mathew McCubbins. 2013. Concepts of Law. Southern California Law Review 86/3:517-72.

Winter, Steven. 2001. A Clearing In the Forest: Law, Life, and Mind. Chicago-London: The University of Chicago Press.

Wróblewski, Jerzy. 1990. Rozumienie prawa $i$ jego wykładnia. Wrocław-Warszawa-Kraków-Gdańsk-Łódź: Zakład Narodowy im. Ossolińskich. 